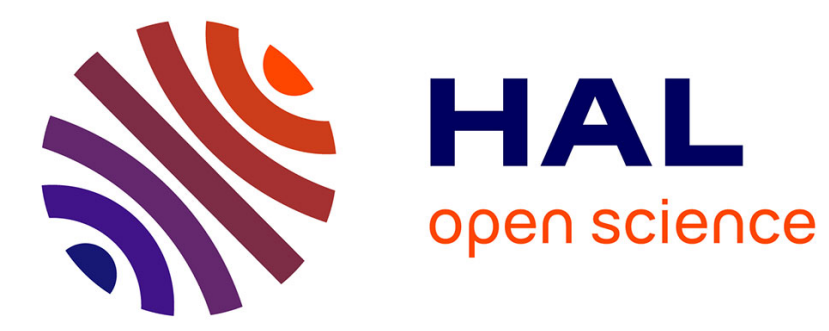

\title{
Translating ion physics from Cambridge to Oxford: John Townsend and the Electrical Laboratory 1900-1914
}

Benoit Lelong

\section{To cite this version:}

Benoit Lelong. Translating ion physics from Cambridge to Oxford: John Townsend and the Electrical Laboratory 1900-1914. La Lettre de la Maison Française d'Oxford, 1997, 7, pp.123-149. hal-02560365

\section{HAL Id: hal-02560365 \\ https://hal.science/hal-02560365}

Submitted on 1 May 2020

HAL is a multi-disciplinary open access archive for the deposit and dissemination of scientific research documents, whether they are published or not. The documents may come from teaching and research institutions in France or abroad, or from public or private research centers.
L'archive ouverte pluridisciplinaire HAL, est destinée au dépôt et à la diffusion de documents scientifiques de niveau recherche, publiés ou non, émanant des établissements d'enseignement et de recherche français ou étrangers, des laboratoires publics ou privés. 


\section{Translating ion physics from Cambridge to Oxford: John Townsend and the Electrical Laboratory 1900-1914.1}

\section{Introduction}

he postgraduate career of John Sealy Edward Townsend
(1868-1957) occured in three places: Dublin, Cambridge,
and Oxford. Townsend graduated in 1890 at Trinity College, Dublin. He spent the five following years there teaching mathematics. In 1895 Townsend obtained an 1851 Exhibition Scholarship to Cambridge University, where he worked as a Research Student in the Cavendish Laboratory of J.J. Thomson. In 1900 he was appointed the first Wykeham Professor of Physics in Oxford, in order to supplement Robert Bellamy Clifton, Professor of Experimental Philosophy. Clifton's responsibility was to teach Light, Heat and Sound, and Townsend's Electricity and Magnetism. ${ }^{2}$

We will see that Townsend sought to implement in Oxford practices and values inherited from the Cavendish regime. It proved to be a difficult enterprise, Oxford being an environment different from Cambridge. In this paper I will be interested in the making of Townsend's Electrical Laboratory, in the shaping of its scientific and social identity, in the establishment of its links with various actors in the outside world, and I will try to relate this story both to the institutional and cultural peculiarities of Oxford and to the international development of ion physics.

To provide a comparative analysis, I will use the international diaspora of the physicists trained by J. J. Thomson. Most of them left Cambridge at the turn of the century, and tried like Townsend to transfer

\footnotetext{
'This paper will be published in Robert Fox and Graeme Gooday (eds), The Clarendon Laboratory and Oxford physics to 1939, Oxford (forthcoming). For valuable comments and criticism, I am endebted to Isobel Falconer, Robert Fox, Janet Howarth, Roger Hutchins, Jack Morrell, Dominique Pestre, Simon Schaffer and Andy Warwick. The following abbreviations are used: $A C P$, Annales de Chimie et de Physique; BSFP. Bulletin des séances de la Société Française de Physique; $C L A$, Clarendon Laboratory Archives, Oxford; $C U L$, Cambridge University Library; $D C A$, Drapers' Company Archives, London; $L P$, Langevin Papers, Paris; $O U A$, Oxford University Archives; $O U G$, Oxford University Gazette; $T P$, Townsend papers, Bodleian Library, Oxford.

2 von Engel (1957), 257; Thaddeus J. Trenn, 'Townsend, John Sealy Edward', DSB, 445-447.
} 
the 'Cavendish style' elsewhere in the world, especially in Canada, France and the United States. Comparing their experiences helps to identify what was specific to Townsend in Oxford.

\section{Townsend in Cambridge, 1895-1900}

In 1895 a new admission system was established by Cambridge University, which allowed some 1851-Exhibition scholars, although they were not Cambridge graduates, to do research for one or several years as Advanced Students in the Cavendish Laboratory. Townsend was among the first accepted and arrived in Cambridge in October 1895, together with Ernest Rutherford (from New Zealand) and J. A. Mc Clelland (from Galway). They were followed in 1896 and 1897 by several young physicists including Richardson, Craig-Henderson, Barkla and H. A. Wilson from Britain; Child, Owens and Zeleny from the United States; Mc Lennan from Canada; and Langevin from France. These 'Advanced Students' formed a new community in the laboratory. They experienced a certain exclusion by students and staff trained in Cambridge, who perceived them as 'competitors for the limited facilities in the way of apparatus and the services of the workshop, and also... for the attention and sympathy of the Professor'. ${ }^{3}$ The newcomers consequently formed a separate group, cemented by strong friendships. Townsend was particularly linked to Rutherford and Langevin. In contrast to the Cambridge students, the new scholars shared a strong enthusiasm for Thomson's researches on electrical discharges, cathode rays and conducting gases, and especially for his most cherished scientific object: gaseous ions. ${ }^{4}$

In Cambridge, Townsend became inculcated with what has been called the 'Cavendish style' of experimental physics, which is well known to us through the work of John Heilbron, Isobel Falconer, Peter Galison, and others. Its main characteristics were the following : the charismatic leadership of J. J. Thomson; a material culture composed of quadrant electrometers, vacuum tubes and ionized gases; an enthusiasm for 'advanced' research on ions, electrons, and other 'fundamental' particles; a literary rhetoric based on theoretical hypotheses followed by experimental confirmations; a scientific approach based on reductionism and microphysics; a disdain for 'applied' science, engineering and high-precision measurements; training through laboratory collaborations and joint

\footnotetext{
${ }^{3}$ R. J. Strutt (the fourth Baron Rayleigh), Life of Sir J. J. Thomson, O. M., Cambridge, 1942, p. 60. Quoted in Kim (1995), 215.

${ }^{4}$ Sviedrys (1976); Kim (1995).
} 
publications; and a social distance between undergraduates and research students. ${ }^{5}$

This physics differed markedly from practices and values in the Cavendish Laboratory before the appointment of JJ Thomson. Under the previous directors Maxwell and Rayleigh, the laboratory's material and intellectual culture was that of the measurement and standardisation of electrical resistances. Then the Cavendish was marked by its links with the electrical industry, its cult of precision, its distrust of microphysics, its care over teaching. Gooday has shown that almost every British laboratory shared these features in the last third of the century. Therefore, Thomson's new group formed a contrast with the practices and values of Victorian physics as a whole. ${ }^{6}$

In Cambridge, Townsend immediately adopted Thomson's research program. He designed a new method to measure the coefficient of recombination of ions, and another one for their coefficient of diffusion. ${ }^{7} \mathrm{He}$ examined a new case of gaseous conduction: gases recently prepared by chemical reactions (for instance hydrogen and oxygen produced by electrolysis). He learned with C.T.R. Wilson how to build cloud chambers, and used them to perform the first measurement of the elementary ionic charge. ${ }^{8}$ In 1900 , having published more than 2 papers a year since 1895, Townsend was one of the 3 most prolific Cavendish students together with Wilson and Vincent. ${ }^{9}$ But his enthusiasm had clearly decreased, as he wrote to Rutherford: 'I wish we had opportunities here of doing work outside the Cavendish as I must confess that eternally working at ions is beginning to be tiresome'. ${ }^{10}$

Nevertheless, through his work on ions, Townsend had accumulated several academic honours which distinguished him from other Advanced Students. He had been elected to a Trinity College Fellowship in 1899.11 Being a mathematical expert, he was given the course of mathematics for physicists by Thomson in $1900 .^{12}$ In 1898 , he obtained the Clerk Maxwell Scholarship, a much coveted award since it was exceptionally generous ( $£ 200$ a year). It had never before been offered to a

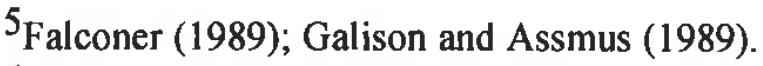

${ }^{6}$ Gooday (1990); Schaffer (1992).

${ }^{7}$ Townsend, 'Application of diffusion to conducting gases', PM, 45 (1898), 469-480; 'The diffusion of ions into gases', PT, A, 193 (1899), 129-158.

${ }^{8}$ Townsend, 'Electrical Properties of Newly-prepared Gases' PM, 45 (1898), 125-151.

${ }^{9} \mathrm{Kim}$ (1995), 222.

${ }^{10}$ Townsend to Rutherford, 27 March 1900, CUL, Add 7653, T74.

$11_{\text {Kim (1995), } 216 .}$

${ }^{12}$ Falconer (1989), 21.
} 
non-Cambridge man and would not be so again until $1910 . .^{13}$ His work interested Lord Kelvin with whom he exchanged preprints and letters, and who wrote him a testimonial for a professorship in University College. ${ }^{14}$

As a rising star Townsend came into conflict with J. J. Thomson. In 1900 Townsend proposed a new collision theory which explained Stoletow's results on the photoelectric effect. ${ }^{15}$ At the outset, Thomson preferred his own explanation, which was based on a layer theory and had been published in December 1899. Later in 1900 he published a paper suggesting that collisions would produce Stoletow's results, but without mentioning Townsend. ${ }^{16}$ Townsend was furious about Thomson's omission and doubtful about his conversion : 'J. J. Thomson has been like a weathercock on all this subject during the last 9 months. You will notice that I communicated my paper myself. I don't know how much of it he agrees with, as he stuck vehemently to his theory of layers as an explanation of my results and Stoletow's. The layers theory is I believe absolute rot'. ${ }^{17}$

The new Advanced Students did not stay more than a few years in the Cavendish, their financing allowing only a temporary stay. Langevin came back to Paris in June 1898, defended his thesis in 1902, and became 'Professeur suppléant' in the Collège de France in 1903. ${ }^{18}$ In September 1898, Rutherford moved to Montréal, where he had been appointed Professor of Physics at Mc Gill University. ${ }^{19}$ In 1899 , Zeleny returned to the University of Minnesota, where he had been Assistant Professor since 1896, and became Associate Professor in 1900 and Professor in 1909.20 Therefore, when Townsend was appointed to Oxford, most of his friends had already left the Cavendish for positions in Britain, Canada, America, France, Poland, India, etc... Hence his career is only one example of the international 'diaspora' of Cavendish physicists.

${ }^{13} \mathrm{Kim}$ (1995), 220; Falconer (1989), 19.

14 Townsend-Kelvin correspondence, CUL, Add7342, T573-T578.

15 Townsend, 'The conductivity produced in gases by the motion of negatively charged ions', Nature, 62 (1900), 340.

16 Thomson, 'The Genesis of Ions in the Discharge of Electricity through Gases', $P M, 50$ (1900), 278-283.

17 Townsend to Rutherford, 14 January 1901 (wrongly dated 14 January 1900), CUL, Add 7653, T73.

18 Paul Langevin, Notice sur les travaux scientifiques de M. P. Langevin, Gauthier-Villars, Paris, 1909, p. 3.

${ }^{19}$ Heilbron (1979).

${ }^{20}$ Fudano (1990), pp. 445, 473. 


\section{Implementing ion research outside Cambridge}

Townsend arrived in Oxford in January 1901. He was very gratified by his new professional situation. He wrote to Rutherford:

I am in great luck getting the professorship here. It is a very easy job, I have only to teach Electricity \& Magnetism and Clifton does the other branches of physics. We are quite independant \& I am going to have a separate lab for myself. The work will be very light and I will have plenty of time for research. If I like I need only lecture two days a week for two terms in a year, but of course I will do more than that. ${ }^{21}$

Townsend's enthusiasm owed much to Oxford's reputation in late Victorian Britain. In the 1860s the superiority of Oxford to Cambridge with respect to facilities for science teaching had been widely acknowledged. Yet in the 1880s the situation changed 'and Oxford acquired a reputation that dogged it well into the twentieth century as a university particularly illadapted, even hostile, to science'. ${ }^{22}$ The famous dictum 'Oxford for Arts, Cambridge for Science' was firmly established at the turn of the century. ${ }^{23}$ Oxford was known for its grandiose Gothic buildings, for the glamour of college life, and for the domination exerted by professors of Law, Literature and Arts. Therefore it is easy to understand why Townsend was charmed (he wrote to Rutherford that 'Oxford is a very jolly place') and why he was also surprised to discover that 'most of the classical men stick up for science.'.24

Townsend's salary was about $£ 500$ per year. He was paid and accomodated by New College. Merton College provided $£ 700$ for 'fitting up the laboratory and $£ 250$ per year for the first two years for assistance and maintainance'. Townsend used these grants to buy electrical instruments, mainly for teaching. In 1901, a temporary classroom and a workshop were allocated by the University, followed by three more rooms in February 1902 on the first floor of the University Museum. ${ }^{25}$ At the end of 1901, the Delegates of the Common University Fund had instituted a demonstratorship to which Townsend appointed the Reverend Paul Jerome Kirkby, like him a fellow of New College. Kirkby had graduated in 1891 in mathematics and held a fellowship since $1895 .{ }^{26}$

\footnotetext{
21 Townsend to Rutherford, 14 January 1901 (wrongly dated 14 January 1900), CUL, Add $7653, \mathrm{~T} 73$.

${ }^{22}$ Howarth (1987), 335.

${ }^{23}$ Howarth (forthcoming), 1.

${ }^{24}$ Townsend to Rutherford, 14 January 1901 (wrongly dated 14 January 1900), CUL, Add $7653, \mathrm{~T} 73$.

25 von Engel (1957), 259-60.

${ }^{26}$ Oxford University Calendar for the year 1900, Clarendon Press, Oxford, 1899, p. 485.
} 
From April 1901, Townsend lectured in Electricity and Magnetism. Practical instruction was given by Kirkby from October 1901 onwards. ${ }^{27}$ Meanwhile, Townsend campaigned successfully for a modification of the University syllabus and added to the practical examination the use of electroscopes, magnetometers, ammeters, voltmeters and ballistic galvanometers. The previous syllabus required the mastery of only one electrical instrument, the tangent galvanometer. Reforming the syllabus and exam enabled Townsend to transform his laboratory into an indispensible facility for students. It allowed him to create, so to speak, a new clientele, a new market for his laboratory classes. ${ }^{28}$

Townsend developed not only teaching but also research. He accumulated the instruments and the skills necessary to reproduce the Cavendish Laboratory's material culture. G. A. Bennett was engaged as laboratory assistant; he was 'a skilled mechanic', and - most importantly - a glass blower able to make vacuum tubes. S. W. Bush was engaged as instrument maker; he had been in the employment of the Cambridge Scientific Instrument Company, and was able to make quadrant electrometers. Townsend bought the necessary instruments to produce and measure ionic phenomena: electrical cells, X-ray tubes, quadrant electrometers. ${ }^{29} \mathrm{He}$ also tried to inculcate the methods and values of ionic physics. He undertook a long laboratory study with Kirkby (a work on ionic collisions in hydrogen), leading to a joint paper published in June 1901. ${ }^{30}$ Another paper was published by Kirkby alone in February 1902. At that time, Kirkby was not yet an 'ion physicist' in the Cambridge sense of the word. Whereas Cambridge papers and textbooks usually presented formalized schemes of electrical connections, he published a threedimensional drawing of his apparatus showing its external physical shape but not its internal electrical structure. His vocabulary was sometimes different too. For instance, Kirkby explained that ions were 'disintegrating' molecules (instead of 'dissociating' them); or that there was an 'extraordinary' difference between positive and negative ions (such an

${ }^{27}$ Townsend, 'Report of the Wykeham Professor of Physics, 1901', OUG, 32 (1901-1902), 648 .

${ }^{28}$ OUA, Natural Science Minutes 1892-1912, FA4/13/1/2, pp. 92, 94, 107; Natural Science Reports 1892-1912, FA4/13/2/1, 27/04/1903.

${ }^{29}$ Townsend, 'Report of the Wykeham Professor of Physics, 1901'; 'Report of the Wykeham Professor of Physics, 1902', OUG, 33 (1902-1903), 549-550.

${ }^{30} \mathrm{~J}$. S. Townsend, P. J. Kirkby, 'Conductivity produced in hydrogen and carbonic acid gas by the motion of negatively charged ions', $P M, 1$ (1901), 630-42. 
enthusiasm would never appear in the dry and objective tone of Cambridge papers). These singularities disappeared in Kirkby's later publications. ${ }^{31}$

In this work of accumulation and reproduction, Townsend's network and allies played a crucial role. Lord Kelvin helped him to obtain a $£ 100$ grant from the Royal Society to buy electrical cells. ${ }^{32}$ Townsend visited Langevin in Paris and bought there the high-quality X-ray tubes produced by Victor Chabaud. ${ }^{33}$

The 'ion diaspora' generated similar episodes elsewhere in the world. Most of the Cavendish physicist appointed to other laboratories beyond Cambridge tried to perform and publish new experiments on gaseous ions, to transmit their know-how and to create research schools built on the Cavendish model. In Montréal, Rutherford immediately undertook new experiments on ions and taught the young Canadian Mc Clung how to measure their rate of recombination. ${ }^{34}$ In Paris, from 1902 onwards, Langevin taught the Cavendish Laboratory methods. His demonstrator Eugène Bloch used them to detect ions in phosphorus emanation, to measure their speed, and to establish their condensation properties. Similar episodes occured with Mc Lennan in Toronto ${ }^{35}$, Zeleny in Baltimore ${ }^{36}$, and Cunningham in Calcutta. ${ }^{37}$ Their diaspora generated an international network of ion specialists. These physicists frequently exchanged letters and visited each other. Most of their scientific publications responded to each other's work.

\section{Townsend versus Clifton}

Although formally created in 1900 , the Wykeham chair of physics already had a long history. In 1877, Clifton had explained to the Oxford Commission that his teaching duties were so heavy that he had had to give up practical instruction in Electricity and Magnetism in order to teach correctly the other subjects, Heat, Light and Sound. In 1878, the Commissioners recommended the foundation of the Wykeham Chair of Physics by New College to supplement Clifton. Unfortunately, in the

\footnotetext{
${ }^{31} \mathrm{P}$. J. Kirkby, 'On the electrical conductivities produced in air by the motion of negative ions', 3 (1902), 212-25.

32 Kelvin to Townsend, 9 December 1901, CUL, Add 7342, T575; Townsend to Kelvin, 13 December 1901, T577; Kelvin to Townsend, 14 December 1901, T578.

${ }^{33}$ Townsend to Langevin, 5 March $1901, L P$, L76/72.

${ }^{34}$ Heilbron (1979), 50.

35 Gingras (1991), pp. 30-31.

${ }^{36}$ Fudano (1990), p. 472.

${ }^{37}$ Cunningham to Langevin, 10 November 1903, LP, L74/36.
} 
following years New College constantly delayed the creation of the chair by repeatedly giving priority to their own building projects whilst suffering from a loss of college income due to the agricultural depression. ${ }^{38}$

Clifton's situation deteriorated. The number of students kept on increasing in the $1880 \mathrm{~s}$. Clifton repeatedly asked for more rooms, posts and grants, which were systematically refused. Significantly, his permanent argument was the necessity to re-start practical instruction in Electricity : 'it is much desired by students who are anxious to take advantage of the openings presented for employment in connection with scientific work by the recent development of electrical engineering'. ${ }^{39}$ In 1894 Oxford University tried to obtain funds from the Drapers' Company for the construction of an Electrical Laboratory. ${ }^{40}$ Later, Thomas Fowler, ViceChancellor of Oxford University deplored the fact that ' students who require advanced teaching in (Electricity and Magnetism) are obliged to have recourse to foreign or other British Universities, or to some of the University Colleges', which was a 'notable deficiency in our teaching'. ${ }^{41}$ This suggests that, because of the growing employment in electrical industry, the University recognized the need to resume pratical instruction in Electricity and Magnetism; but that Clifton was no longer credible as the right man for such an expanded commitment.

From 1901 onwards, Clifton and Townsend therefore taught the same students, preparing them for the same degree (but not for the same subjects). It meant that they competed for the same resources, and that led to bitter rivalry. In 1901, when the newly appointed Townsend had no laboratory, Clifton did not allow him to experiment in the Clarendon Laboratory. Townsend and Kirkby had to rent rooms in the Observatory, and later in the Physiological Laboratory. When space on the first floor of the University Museum became available, Clifton requested it for his Preliminary teaching. He was furious to see it given to Townsend. In 1903, Townsend timetabled his lectures to clash with Clifton's: suddenly deprived of an audience, Clifton had to cancel his lectures! ${ }^{42}$

Townsend's strategy was to discredit Clifton in order to capture his clientele and his resources. In 1903, he made a proposal to teach all the branches of physics to the preliminary students, i.e. not only Electricity and

\footnotetext{
${ }^{38}$ Gooday (1989), chapter 6.

${ }^{39}$ Clifton, 'Proposed Extension for the Clarendon Laboratory', 3 Feb 1887 (Bodleian scrapbook $n^{\circ} 2$, GA oxon b. 139, f.89).

${ }^{40} D C A$, Court of Assistants minute books, 6/12/1894.

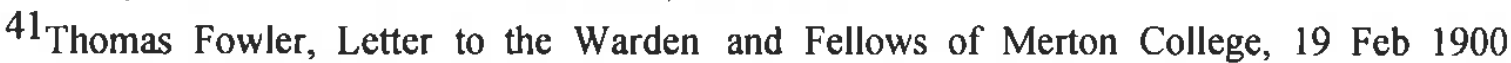
(Bodleian scrapbook $n^{\circ} 2$, GA oxon c.281, f.17).

${ }^{42}$ Townsend's and Clifton's annual reports of 1901, 1902 and 1903, in $O U G, 32,33$, and 34.
} 
Magnetism, but also Clifton's subjects (Heat, Light and Sound). This was accepted in 1904 by the Hebdomadal Council of the University. To finance this additional teaching duty, Townsend was given a sum of $£ 600$ to buy new instruments, and an annual grant of $£ 200$ which allowed him to recruit two more demonstrators, Craig and Lattey. Clifton bitterly complained about the heavy loss caused to his own income by the new arrangement. He soon lost 2 of his 4 demonstrators, no longer being unable to pay them all. 43

A comparison of Townsend's and Clifton's annual receipts in 19011914 shows the consequences upon student fees. From 1904 to 1905 Clifton's fees diminished from $£ 314$ to $£ 121$, and Townsend's rose from $£ 125$ to $£ 583$. The figures are evidence of a transfer of credibility vis-à-vis the University. Sums given by the University to Clifton had initially been higher than Townsend's, but whereas they remained constant, Townsend's increased so that the ratio changed. ${ }^{44}$

There were many differences between Clifton's and Townsend's management styles and institutional rhetorics. Clifton gave priority to Preliminary students at the expense of Honour students and original research. In his annual reports to the University he then constantly asked for more money and space to improve the teaching of Honour students and to allow his staff to do research. Conversely, Townsend had little interest in Preliminary students. He often paid advanced students to teach them. He encouraged his demonstrators to perform experiments and to publish in scientific journals. He asked for resources to improve preliminary teaching. ${ }^{45}$

The laboratories also had very different scientific ideals. This has been reported by Hurst, who learnt physics in both settings in 1901-1903:

The laboratory course at the Clarendon was very well organized, as each experiment had a card with a clearly-written description. A great point was made of accuracy in results, and a student could not pass on from an experiment until his numerical result was within certain limits of accuracy.

Instruments were perfectly tuned, and then treated as objects of distant worship:

Clifton... was describing to us how to use a certain instrument. He pointed out that the zero of its scale was in error, and a small correction must be added to its reading. One of the group said 'Would it not be a good thing to make a scratch on the scale to indicate the true zero ?' Clifton

\footnotetext{
${ }^{43}$ Townsend's and Clifton's annual reports of 1904, OUG, 35 (1904-1905), 572-3;; see also Heilbron (1974), p 36, n 19.

${ }^{44}$ Townsend's and Clifton's departmental accounts, OUG, 35 (1904-1905), Appendix, 22, 24; OUG, 36 (1905-1906), Appendix, 22, 24.

45 Townsend's and Clifton's annual reports in $O U G$.
} 
said 'Don't talk to me about putting a scratch on a scale; it sends a shiver down my spine'.

Such a respect for precision and instruments did not exist in Townsend's laboratory. There Hurst learnt that an agreement to the first order between gaseous phenomena and ion theory was more than enough. ${ }^{46}$

This contrast is partly due to the fact that Clifton and Townsend belonged to different generations of physicists. Clifton was 64 in 1900. To a large extent he belonged to the Victorian tradition described by Gooday which ranked teaching before research as a professional duty, with precision being a technical and moral imperative of scientific conduct: By contrast Townsend was 27 in 1900 . He had been trained by J. J. Thomson in the Cavendish Laboratory. Like his master, he perceived himself primarily as a researcher, considered teaching as a mere financial necessity, and viewed excessive precision as an obstacle to the advancement of microphysics.

Most ion physicists had a strong research ethos. That inclination generally conflicted with their universities, which paid them to teach physics, and seldom gave them resources for research. This tension took different forms in each context. Back in Minnesota University, being now 'associate professor' in the Physics Department, John Zeleny's research orientation was obstructed by his colleagues' indifference, by instruments convenient for instruction but not for research, and by heavy teaching duties, which was for him 'an unavoidable cruelty' according to his biographer Erikson. ${ }^{47}$ Back in Toronto University in 1901, Mc Lennan experienced similar difficulties. ${ }^{48} \mathrm{He}$ wrote to Langevin: 'I have been very very (sic) busy since coming back to Canada and have had but little time for any research, and so feel rather disappointed' ${ }^{49}$ Rutherford's situation in Montréal looked better: 'I suppose I should consider myself very lucky as the laboratory there is about the finest equipped in the world as regards scientific instruments. I have 3 demonstrators... so I should have little time for research'. ${ }^{50}$ In Paris, Langevin had little space, and frequently performed experiments on the table of his lecture room. Preparing his lectures required 'a large amount of bibliographical work'. However, being a professor in the Collège de France, he was not responsible for undergraduate teaching.

\footnotetext{
${ }^{46}$ Hurst (1969); Townsend and Hurst, 'The genesis of ions by the motion of positive ions, and a theory of the sparking potential', $P M, 8$ (1904), 738-49.

${ }^{47}$ Fudano (1990), pp, 471-2,

${ }^{48}$ Gingras (1991), p. 51.

${ }^{49} \mathrm{Mc}$ Lennan to Langevin, II December 1901, $L P, \mathrm{~L} 76 / 01$.

${ }^{50}$ Rutherford to Langevin, 3 September $1898, L P, L 76 / 40$.
} 
Consequently he had time to give to his research students and to his own scientific work. ${ }^{51}$

Another aspect was that most ion physicists encountered resistance from local communities sharing different intellectual and professional values. In Paris, Langevin met the traditional French hostility against atomism. In 1900, 1902 and 1903, he published detailed epistemological justifications of the existence of ions, and of their accessibility to experimental investigation. ${ }^{52}$ In Montréal, Rutherford confronted a research tradition, high precision measurement of thermodynamic quantities, which was represented by the assistant demonstrator, Barnes, by 2 other demonstrators, and by 3 graduate students. Heilbron reports that Rutherford did not like their 'old fashioned physics, with its tedious exactness and proximity to engineering'. Conversely, his demonstrators scorned him for the low precision of his ionic measurements and he could train ion physicists only among undergraduates. In 1900 two distinct research groups coexisted within Montréal's laboratory: Barnes' on calorimetry and Rutherford's on ions and radioactivity. ${ }^{53}$

The opposition between Rutherford and Barnes parallels the conflict between Townsend and Clifton. Both opposed two cultures with different instrumental bases and different attitudes vis-à-vis precision, teaching and engineering. In Montréal this contrast was also due to the fact that physicists belonged to different generations. High-precision calorimetry had been introduced there by the previous director, Callendar. Callendar had been trained in the Cavendish Laboratory in the pre-Thomsonian tradition of electrical resistances. His experimental approach, like Clifton's, belonged to Victorian precision physics. ${ }^{54}$ But the conflicts had different endings. In Montréal collaborations commenced from 1903 onwards between calorimetry and radioactivity. This difference owes much to the institutional conditions. Rutherford was the head of his department: the calorimetry group was under his administrative and financial control. By contrast, the Oxford situation shows two directors independent from each other and competing for the same resources - which led to the elimination of one by the other.

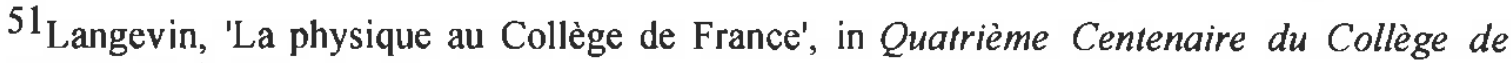
France, Paris, 1931 , p. 74.

${ }^{52}$ Langevin, 'Sur l'ionisation des gaz', $B S F P$ (1900), p. 39; 'Les ions dans les gaz', BSIE, 1, 17 (1900), 203-222; 'Recherches sur les gaz ionisés', BSFP (1902), 45-47; 'Recombinaison et mobilité des ions dans les gaz', $A C P$ VII, 28 (1903). 433-530.

53 Heilbron (1979), 42-50. Quotation p. 45.

${ }^{54}$ Gingras (1987).
} 


\section{Oxford chemists and college fellows}

Apart from Clifton's group, Townsend met another scientific community in Oxford: the chemists. Townsend's first research student was H. E. Hurst. In 1905 he finished his dissertation, a study of collisions between ions in hydrogen. Two examiners were appointed: Townsend and Herbert B. Baker. ${ }^{55}$ Baker was Lee's Reader in Chemistry at the private laboratory of Christ Church. He was a chemist, and not a physicist, so his appointment as an examiner warrants some comment. First, Baker belonged to a research tradition developed by Oxford chemists since the 1880s: the study of chemical reactions between gases, especially the combination of hydrogen and oxygen by electric sparks. More than any physicist in Oxford, Baker was an expert in the electrical properties of gases. ${ }^{56}$ Second, in Oxford chemistry was much more developed than physics. Of all the natural sciences, it was the best catered for in college laboratories. Chemistry was much more popular among undergraduates than was physics. Oxford chemical research covered some territories - like electricity in gases - that in Cambridge were appropriated by physicists. ${ }^{57}$ That Baker appeared in Oxford as the most competent examiner for Hurst is therefore not surprising.

However, Baker strongly criticized Hurst's work. Hydrogen had been prepared by the electrolysis of potassium hydrate, ie. not with Baker's method which required the electrolysis of barium hydrate. Consequently, Baker considered that Hurst's hydrogen was not pure enough, and that these impurities had certainly affected his numerical results. He refused to accept the application for the degree. ${ }^{58}$ Hurst had to perform new experiments using samples of barium hydrate provided by Baker. ${ }^{59}$ This new method became assimilated in Townsend's laboratory. Kirkby and Haselfoot started using barium hydrate 'kindly supplied' by Baker. ${ }^{60}$

Kirkby's itinerary deserves some attention, because it sheds light on the role played by Oxford chemistry - and by the collegiate structure of the University - in the development of Townsend's laboratory. From 1904

\footnotetext{
55 OUA, Natural Science Minutes 1892-1912, FA4/13/1/2, pp. 123, 125, 127.
}

$56 \mathrm{~J}$. F. Thorpe, 'Herbert Brereton Baker 1862-1935', Obituary Notices of Fellows of the Royal Society, 1 (1935), 523-526; H. B. Baker, 'Ionisation of gases and chemical change', Nature, 84 (1910), 388-9; Howarth (1987), p. 338.

${ }^{57}$ Howarth (1987), 337-9; Howarth (forthcoming), 7-9; K. J. Laidler, 'Chemical Kinetics and the Oxford College Laboratories', Archives for the History of the Exact Sciences, 38 (1988), 197-283.

${ }^{58}$ OUA, Natural Science Reports 1892-1912, FA4/13/2/1, pp. 39, 41 .

${ }^{59}$ Hurst (1969).

${ }^{60}$ C. E. Haselfoot, P. J. Kirkby, 'The electrical effects produced by the explosion of hydrogen and oxygen', $P M, 8$ (1904), 471-81. p. 481. 
to 1907 Kirkby's experiments showed a great intellectual and technological proximity to Baker's research line. In 1904 he examined one of Baker's favourite reactions, the explosion of hydrogen and oxygen; and he tried to explain it with Townsend's concepts, ie by collisions between ions. ${ }^{61}$ In 1905, with the help of Baker, he designed a new apparatus to study this reaction at low pressures. ${ }^{62}$ His paper was reviewed by the Journal of the Chemical Society as a contribution to 'Inorganic Chemistry', and not to 'General and Physical Chemistry', as was usually the case for ion physics papers. Meanwhile, Kirkby and Baker collaborated within Oxford University, creating a 'Committee for Engineering and Mining'. ${ }^{63}$

Thus Kirkby borrowed his research goals, theoretical tools and material technologies from two different fields, Cambridge ion physics and Oxford gaseous chemistry. This disciplinary hybridization was highly contingent. In Paris, Langevin's students, for instance Bloch in 1905, explicitly rejected any interest in the chemical properties of gaseous ions. ${ }^{64}$ Each ion lab drew upon new instrumentation and concepts from local scientific communities. In Montreal, Rutherford collaborated with Barnes, using his expertise and his thermometers to measure the energy required to produce an ion. ${ }^{65}$ In Paris, Maurice de Broglie used the ultramicroscope designed by Jean Perrin to observe Brownian motion: he transformed it in order to see macroscopic ions and to photograph their trajectories. ${ }^{66}$ In Cambridge, Wilson's cloud chamber established a link between ion physics and meteorology: the device could be used either to investigate cloud formation or to photograph the tracks and collisions of electrified particles. ${ }^{67}$ These exchanges owed much to locally available expertise, but also to social networks allowing the transfers or even requiring them. Examples are, in Paris, the informal circles of Langevin, Perrin and Curie; or, in Oxford, the Natural Sciences Faculty Board or Amabel Moseley's dinner parties. ${ }^{68}$

\footnotetext{
${ }^{61}$ P. J. Kirkby, 'The effect of the passage of electricity through a mixture of oxygen and hydrogen at low pressure', $P M, 7$ (1904), 223-232.

${ }^{62} \mathrm{P} . \mathrm{J}$. Kirkby, 'The union of hydrogen and oxygen at low pressures through the passage of electricity', $P M, 9$ (1905), 171-85.

${ }^{63}$ OUA, Natural Science Minutes 1892-1912, FA4/13/1/2, p. 149.

${ }^{64}$ E. Bloch, 'L'Ionisation par le Phosphore et par les Actions Chimiques', Le Radium, 2 (1904), 33-39.

${ }^{65}$ Heilbron (1979), 58.

${ }^{66}$ Maurice de Broglie, 'Etude sur les suspensions gazeuses', Le Radium (1909), 203.

${ }^{67}$ Galison and Assmus (1989).

${ }^{68}$ Heilbron (1974), p 41.
} 
These comparisons also show that Kirkby performed very few transfers. Conversely, in Paris Broglie had the skills required to use an ultramicroscope: he taught them to other ion physicists in Langevin's laboratory, for instance to Brizard, Reboul and Léon Bloch. In Cambridge, C.T.R. Wilson did the same with his cloud chamber in the Cavendish Laboratory. On the contrary, Kirkby did not transmit his new chemical technical know-how to other workers in the Electrical Laboratory. This seems to reflect his independence and his growing isolation in the department. ${ }^{69}$

It was firstly a financial and institutional independence. Kirkby was a fellow of New College which provided him a salary and accomodation. His fellowship was an income independent of his demonstratorship. Moreover, among Townsend's demonstrators, Kirkby alone was a college fellow and, as such, was not paid by Townsend but directly by the University treasurer, W. B. Gamlen. In 1910, Kirkby resigned his demonstratorship to become the incumbent of Saham Rectory, Watton, Norfolk. ${ }^{70}$ Then Townsend had to negotiate with Gamlen to have Kirkby's salary paid to his successor Pidduck. ${ }^{71}$ Thus Townsend experienced what Jack Morrell has called 'the peculiarities of the Oxford system, which gave a professor charge of a university laboratory but which in part staffed it with college fellows who were statutarily independent of him' ${ }^{72}$ We have seen that this independence gradually became a scientific one too. Kirkby's experiments were far more distant to Townsend's research line than were those of other demonstrators like Brown, Gill, Hurst or Smith. After 1910, Kirkby continued experimenting in Oxford, but not in Townsend's lab. He worked in the Chemistry department with Perkin's demonstrator James E. Marsh. In 1913, they published together a study on the explosion of azoimide. ${ }^{73}$

Kirkby's scientific and social behaviour is easier to grasp through a comparison with Harry Moseley. Although he graduated in Oxford, Moseley felt alien to the place. As an undergraduate student at Trinity College, he worked in the Balliol-Trinity laboratory and built there a primitive cloud chamber; 'partly from tension over his course of study he

\footnotetext{
${ }^{69}$ Maurice de Broglie et L. Brizard, 'Contribution à l'étude de l'ionisation des gaz en présence de réactions chimiques', Le Radium (1910), 164.

70 von Engel (1957), 263.

71 OUA, 'Electrical Laboratory', UC/FF/77/1, Kirkby to Gamlen, 16/10/1910; Townsend to Gamlen, 19/10/1910; Townsend to Gamlen, 24/02/1911.

${ }^{72}$ Morrell (1993), 122.

${ }^{73}$ P. J. Kirkby, J. E. Marsh, 'Some electrical and chemical effects of the explosion of azoimide', PRS, 88 (1913), 90.
} 
obtained a second class degree in the bookish Oxford honour schools' ${ }^{74}$ In 1910 he moved to Rutherford's laboratory in Manchester, where he enthusiastically experimented on radioactivity sometimes 16 hours a day. In 1912, news of von Laue's discovery of X-ray diffraction reached him from Germany. He immediately moved to Bragg's laboratory in Leeds to learn the new technique. Back in Oxford in 1913, he felt that 'Things seem to move slowly here compared to Manchester'. ${ }^{75}$ In 1914, Moseley's experiments on spectra and rare earths were already known, praised and used on an international level.

The differences with Kirkby are obvious. Kirkby worked 13 years on the same subject, and quietly published less than 1 paper every two years. His work on the chemical action of gaseous ions wasn't mentioned by the three major treatises on ion physics published in 1905, 1906, and 1915. ${ }^{76}$ To the best of my knowledge, nobody outside Oxford paid any attention to it at all. Predictably, Moseley held Kirkby in contempt :

"Firstly he is by nature rather lazy himself, and therefore his ideal is on a less strenuous plane than my own - he would probably think an Oxford fellowship would be the full stretch of my ambition. Secondly, as an Oxford man he looks down on all things outside..."77

More charitably, I would recall that Kirkby's favourite environment was his college. To quote Jack Morrell again

"...the tradition of connoisseurship at high table in fellowship divine sat uneasily with the notion of specialist and allegedly narrow scientific publication. From the college enclave, research could be seen as an ungentlemanly and boorish Germanic notion, and postgraduate supervision as a Yankee device for inserting plebeians into a patrician university". 78

In contrast with Moseley, Kirkby was professionally established, well integrated and at ease in Oxford. For him, research was neither a vital priority nor a route to international fame, but rather a stimulating hobby and a way to socialize with the Oxford chemists.

\section{The Drapers' Company and the teaching of engineering}

Ion research was sometimes financed by industrial companies or private foundations, like Mc Donald or the Carnegie Foundation in

\footnotetext{
${ }^{74}$ Heilbron, 'Moseley, Henry Gwyn Jeffreys', DSB, 542-545. On p. 542.

${ }^{75}$ Moseley to Rutherford, 7 December 1913, quoted in Heilbron (1974), 217.

${ }^{76}$ Abraham and Langevin (1905); Thomson (1906); Townsend (1915).

${ }^{77}$ Heilbron (1974), 169-170.

78 Morrell (1994), 141.
} 
Canada. ${ }^{79}$ In Townsend's case, this role was played by the Drapers' Company, a medieval guild turned into a charitable institution. From 1877 onwards, under political pressures mediated by the City and Guilds of London Institute, the Drapers' Company supported the development of technical education in Britain. ${ }^{80}$ Between 1887 and 1922 the Drapers gave $£ 532000$ to various Universities and Colleges. They funded Physiological or Electrical labs, and Mining or Engineering Departments at London, Cambridge, Sheffield, Leeds, Oxford, and elsewhere. ${ }^{81}$

At the end of the XIXth century, close links were already established between Oxford and the Drapers Company. The Master of the Drapers, the Rev. Henry Boyd, was also the Principal of Hertford College. ${ }^{82}$ In 1894 , the Drapers decided to finance a new building for the Radcliffe Library, in order to support the educational work of the University, especially in those subjects which in more recent times it has been found necessary to include in the course of study'. In 1897, T. G. Jackson was chosen as the architect: 'we may feel confident that the Library in his hands will become not merely a suitable home for the literary studies of our scientific men here, but will be a permanent and attractive memorial of the splendid and thoughtful generosity of the Drapers' Company'. ${ }^{83}$

Townsend joined these local proponents of technical education. On 1 st June 1908, after 3 years of negotiations, the Drapers Company decided 'that Oxford University stands in great need of a new laboratory for the teaching of Physics and Electrical Science' and offered $£ 23000$ for that purpose. ${ }^{84}$ Predictably, the architect was to be Jackson again. Consequently, a new subject was to be added to Townsend's teaching duties. Two weeks later he proposed 'that a committee be appointed to frame a scheme for the inclusion of engineering science as one of the subjects of the Final Honour School of Natural Science', which was accepted in December 1908 by the Hebdomadal Council. Townsend had responsibility for the teaching of two subjects, 'Electrical Engineering and Applied Chemistry' together with his chemist partners, and 'Advanced Applied Electricity and Magnetism' (which included alternating currents, electromagnetic waves, telegraphy and telephony). ${ }^{85}$ The new Electrical

\footnotetext{
${ }^{79}$ Gingras (1991), 64; Heilbron (1979), 57.

${ }^{80}$ Girtin (1964), 336-354; Johnson, (1914-1922), Vol 3, 487.

81 Johnson (1914-1922), Vol 3, pp. 488-9.

${ }^{82}$ Croft (1986), 53.

${ }^{83} D C A$, Court of Assistants minute books, 6/12/1894. 15/7/1897.

${ }^{84} D C A$, Court of Assistants minute books, 1/6/1908.

${ }^{85}$ OUA, Natural Science Minutes 1892-1912, FA4/13/1/2, 16/06/1908; 17/10/1908; 01/12/1908; Natural Science Reports 1892-1912, FA4/13/2/1, p. 64.
} 
Laboratory was inaugurated on 21 June 1910.86 Its style belonged to the Byzantine and Roman architecture favoured by Jackson at the end of his life, instead of the Gothic style of his early career.

The new engineering course seldom attracted more than ten students, which is very low compared with the Preliminary and Advanced courses in Physics, which attracted between 30 and 40 students. ${ }^{87}$ According to Michael Sanderson, historian of British technical education, 'the work there (in the Electrical Laboratory) was not evidently concerned with technical problems of electrical engineering'. ${ }^{88}$ This low involvement is partly explained by the hostility against applied science within the Oxford system, and by the competing course of Jenkin, appointed to the new Professorship of Engineering Science. ${ }^{89}$ But values inculcated in the Cavendish Laboratory probably played a role. Townsend did not show much interest. He never taught Electrical Engineering himself, delegating it to his demonstrators. ${ }^{90}$

\section{Scientific work on collisions, 1901-1910}

In order to assess Townsend and his laboratory in the international context of ion physics, it is best to begin with the 1901-1910 period. A first point is that Townsend's laboratory focused on a specific question, collisions between ions. These physicists measured collisions in different gases, in different conditions of temperature and pressure, ionizing gases with different agents. This question being controversial, they mentioned the 'theory of collision', presenting their results as 'confirmations of Professor Townsend's theory'. ${ }^{91}$ Other ion laboratories specialized too. Langevin's group studied slow moving ions and recombination. McLennan's examined spontaneous ionization in closed vessels. Rutherford's investigated ions

\footnotetext{
${ }^{86}$ Nature, LXXIII, 23 June 1910.

${ }^{87}$ Townsend's annual reports, OUG, 40 (1909-1910), 746; OUG, 41 (1910-1911), 959; OUG, 42 (1911-1912), 988; OUG, 43 (1912-1913), 967; OUG, 44 (1913-1914), 863. On the teaching of engineering in Oxford, see Howarth (1987), 342; Howarth (forthcoming), 17 , 23-27.

${ }^{88}$ Michael Sanderson, The Universities and British Industry, 1850-1970, Routledge and Kegan Paul, London, 1972. p. 39.

${ }^{89}$ C. F. Jenkin, 'Report of the Professor of Engineering Science, 1911', OUG, 42 (19111912), 988.

${ }^{90}$ Townsend's annual reports, 1909-1914.

${ }^{91}$ See for instance H. E. Hurst, 'Genesis of ions by collision and sparking-potentials in carbon dioxyde and nitrogen', $P M, 11$ (1906), 535-552; J. A. Brown, 'An investigation of the potential required to maintain a current between parallel plates in a gas at low pressures', $P M, 12$ (1906), 210-232; E. W. B. Gill, F. B. Pidduck, 'The genesis of ions by collision of positive and negative ions in a gas. Experiments on argon and helium', $P M, 16$ (1908), 280-90.
} 
produced by radium rays (and increasingly radioactivity itself rather than its ionization effects). By contrast, the Oxford group seemed particularly homogeneous in its research topics, which correlates Townsend's reputation as a very authoritarian director. ${ }^{92}$

How were Oxonian results internationally perceived and used ? Here again, a crucial role was played by Townsend's network, by his friends trained in the Cavendish. In 1906, Langevin praised Townsend's theory of ionization by collision for its all-embracing explanatory power, and ranked it as the most important advance in discharge physics since $1900 .{ }^{93}$ Moreover, ionic collisions multiplied charges and allowed the detection of single particles. In 1908, Rutherford and Geiger used the multiplication coefficients measured by the Oxford physicists to design their new particle detector. ${ }^{94}$ It seems that Townsend himself taught them how to produce and stabilize a steady multiplication effect ${ }^{95}$ In his papers, Rutherford frequently mentioned 'Professor Townsend's principle of collision', cited his publications, and publicly gave him credit for the new counting method. ${ }^{96}$

As a research subject, collisions were less important in Cambridge. In 1903 J.-J. Thomson published a new treatise entitled Conduction of Electricity through Gases. He praised Townsend's 'valuable' experiments on collisions but he described his own layer theory of Stoletow's results and ignored Townsend's alternative explanation. ${ }^{97}$ In 1904, Townsend wrote: 'I have lots of things to be done in my particular job on collisions. I am very glad they are not working at it at the Cavendish. I expect J. J. keeps them off it as much as possible'. ${ }^{98}$ In 1906, in the second edition of his treatise, Thomson ignored once again Townsend's explanation of Stoletow's results. He also argued that Langevin's collision concept was inconsistent and had to be dropped. ${ }^{99}$ Townsend responded in 1910 with a small book entitled The theory of ionization by collision, published by Oxford University Press, where he defended his team's results and angrily

\footnotetext{
92 von Engel (1957), 269.

${ }^{93}$ Langevin, 'Recherches récentes sur le mécanisme de la décharge disruptive', Le Radium, 3 (1906), 107-115.

${ }^{94}$ T. J. Trenn, 'The Geiger-Muller counter of 1928', Ann. Sci., 43 (1986), 111-35, pp. $115-$ 118.

${ }^{95}$ Townsend to Rutherford, 10 march 1908, Add 7653, T76.

${ }^{96}$ Rutherford and Geiger, 'An electrical method of counting the number of a-particles from radio-active substances', $P M, 81$ (1908), 141-161, p. 161.

${ }^{97}$ Thomson (1903), 341.

98 Townsend to Rutherford, 9 july 1904, Add 7653, T75.

${ }^{99}$ Thomson (1906), 270-1.
} 
undermined Thomson's layer theory. ${ }^{100}$ Both positions remained unchanged until the war.

\section{After 1910 : international marginalization and local strength}

After 1910, Townsend became gradually marginalized within the new context of international physics. The 1910 s were marked by the consolidation of a new transnational network of physicists, a process initiated by the first two international physics congresses (Paris 1900 and Saint Louis 1904), and continued by the Solvay congresses in 1911 and 1913. A key role was played by the new generation, especially by Langevin, Perrin, and Rutherford. Townsend did not attend these congresses. At the 1911 Solvay meeting on 'Radiation and quanta', Townsend was briefly cited three times. At the 1913 Solvay meeting on 'The structure of matter', only one of Townsend's scientific results was mentioned (his measurement of the ionisation energy of hydrogen in 1910). None of his students was cited. Instead, many discussions concerned specific heats, radioactivity, electronic theories of magnetism, or Brownian motion. None adressed collisions between ions. After 1910, a social and intellectual distance gradually separated Townsend's laboratory from the new 'modern physics' and its networks. ${ }^{101}$

It was also a technological distance. Experimental results examined at the Solvay congresses were produced with equipment very different from Townsend's: X-ray diffraction, ionisation chambers, photoelectric cells, spectroscopes, mass-spectrographs... Access to this new 'symbolic market' required new techniques. This is clearly illustrated by the attitudes of ion physicists in Toronto and Paris. In 1912-1913, Mc Lennan's team in Toronto gradually gave up counting ions in atmospheric air and closed vessels. They started producing mercury spectra. ${ }^{102}$ In Paris, in 1912-1913, the two most prolific ion physicists abandoned ions as well. Maurice de Broglie entered the field of X-ray diffraction and Eugène Bloch ultra-violet spectroscopy. ${ }^{103}$ Townsend's attitude was different. In the 1910 s he bought

\footnotetext{
100 Townsend, The theory of ionization by collision, Oxford University Press, Oxford, 1910 , See also Townsend (1915), 263.

${ }^{101}$ Mehra (1975), pp. 13-72, 75, 78, 81 .

102 J. McLennan, 'On the series lines in the arc spectrum of mercury', PRS, A, 87 (1912), 256; J. McLennan and J. P. Henderson, 'Ionization potentials of mercury, cadmium, and zinc, and the single- and many- lined spectra of these elements', PRS, A, 91 (1915), 485. See also Gingras (1991), 71 .

${ }^{103}$ Eugène Bloch, 'Sur l'emploi des cellules photoélectriques', CRAS (1912); 'Spectres d'étincelle', CRAS (1914); Maurice de Broglie, 'Sur les images successives que présentent les rayons de Röntgen après avoir traversé des cristaux', CRAS, 156 (1913), 1011; 'Sur la réflexion des rayons de Röntgen', Ibid., 1153.
} 
new thermogalvanometers, ammeters, voltmeters and Geryk pumps. ${ }^{104}$ His most expensive new instrument was a liquid air plant to produce a high vacuum. ${ }^{105}$ Townsend sought to improve his technical system, but not to build and use a new one as his Canadian and French counterparts did.

This technological gap is illustrated by Moseley's experience in Oxford. In November 1913, Moseley came back from Leeds to work in Townsend's laboratory. Learning that he wanted to work on X-ray spectroscopy, Townsend required all his 'patience and tact'. Moseley did not find in the Electrical Laboratory the instruments he needed (a Gaede pump and a spectrometer). He complained that Townsend's assistant did not have the necessary skills to help him. The instrument sellers linked to Townsend responded to his demands with slowness and inadequacy. ${ }^{106}$ This reveals a profound difference with Townsend's technical system, with his complex of instruments, phenomena, skills and routine collaborations. Equally significant is the fact that nobody in Oxford took the opportunity to learn the new technology with Moseley (whereas Georges Urbain came from Paris to do so).

Nevertheless, this impression needs to be qualified. Townsend was still internationally known and respected. In 1919, looking for a new president for the Solvay congresses, Brillouin suggested that Lorentz's successor be chosen from among the 'new generation', which meant for him 'Rutherford, Langevin, Perrin, Townsend, etc...' But he seriously considered only the first three, and finally recommanded Langevin. ${ }^{107}$ In 1910 the German editor Marx decided to publish a new treatise in six volumes on 'modern physics'. Townsend was responsible for the volume on gaseous ions. Other contributors included Rutherford and Marie Curie, but not J. J. Thomson. ${ }^{108}$ This reflected the rising leadership of Townsend, but also the fall of J. J. Thomson as the international expert in discharge physics. The third edition of Thomson's treatise was finished in manuscript form in 1913. But it was published only in 1928, in a much revised form. ${ }^{109}$ At the 1913 Solvay congress Thomson presented his new atomic model, which was strongly criticized there by Rutherford and Langevin. In

\footnotetext{
${ }^{104} C L A, \mathrm{C} / 13 / \mathrm{y}, \mathrm{z}$, aa.

105 OUA, 'Electrical Laboratory', UC/FF/77/1, Townsend to Gamlen, 21/11/1911; Townsend to Gamlen, $17 / 12 / 1913$.

${ }^{106}$ Heilbron (1974), 70-72, 95-96. Quotation on p. 95.

${ }^{107}$ Letter from Brillouin to Tassel, quoted in Pierre Marage and Grégoire Wallenbom (eds), Les Conseils Solvay et les débuts de la physique moderne, Université Libre de Bruxelles, 1995. p. 212.

${ }^{108}$ Townsend to Langevin, 11 July $1911, L P$, L76/74.

${ }^{109}$ Thomson's manuscript is in $C U L$, Add. 7654, BD7.
} 
those years Thomson opposed the new views on electrons, even refusing to use their name and keeping his own word of 'corpuscle'. ${ }^{110}$ Townsend's treatise was published in English by the Oxford University Press in 1915. ${ }^{111}$ In summary, it is clear that Townsend successfully built a disciplinary niche, gaseous ions, in which he secured his leadership. This specialty was still important for the design of detectors and experimental set-ups. But it was no longer at the forefront of research on the structure of matter. Townsend's leadership in gas ionization resulted not only from his scientific excellence, but also from Thomson's increasing obsolescence, and from the abandonment of that field by most of its practicioners.

The first world war dispersed Townsend's group. Gill, Tizard, and Edmunds went on military service in 1914. At the end of 1915, Lattey obtained a commission in the Royal Flying Corps and Pidduck one for special duties in the Ministry of Munitions. ${ }^{112}$ Moseley had obtained one in the Royal Engineers in 1914 and after eight months training he was shipped to the Dardanelles as a signal officer. ${ }^{113}$ Contrasting with the 8 physicists provided by the Electrical Laboratory, the Clarendon contributed only I. O. Griffith, an assistant demonstrator, to the war effort. ${ }^{114}$ Moseley's death in August 1915 in a counterattack led by Kemal Ataturk was a shock to Townsend : he wrote to Rutherford (member of the Bureau of Invention and Research since July 1915), asking him to 'move the Inventions board to try \& get some of the very clever physicists, who are now in the army, back to England', and suggesting Bragg among them. ${ }^{115}$

Being 46 in 1914, Townsend had no obligation to join the service. He seems to have nevertheless volunteered for a wireless unit which was to be sent to Russia (and which never materialized). ${ }^{116} \mathrm{He}$ therefore stayed in Oxford. The Electrical Laboratory being almost empty, most of the rooms were given to the Royal Flying Corps in April 1916 - to assist them in establishing the School of Military Aeronautics - and used by them until December 1918.117 The few remaining Preliminary Students were taught by Baynes. Having no Advanced Students anymore, Townsend

\footnotetext{
110 Falconer (1987).

111 Townsend (1915).

112 OUG, XLVI (1915-1916), 545-6.

113'Moseley', DSB, p. 544.

114 Morrell (1992), 266.
}

115 Townsend to Rutherford, 22 Sep 1915, CUL, Add7653, T88. Rutherford was one of the twelve scientists of the Consulting Panel of the Bureau, see Hackmann (1988), p. 98.

${ }^{116}$ Engel (1957), 264; Croft (1986), 57.

117 OUG, XLVII (1916-1917), 556; OUG, XLVIII (1917-1918), 479. 
offered his services to the Royal Naval Air Service. ${ }^{118}$ By September 1915 he had been enroled, had shaved his moustache and was wearing a blue uniform with brass buttons: 'I feel quite a fraud in naval uniform as I would get sea sick if I went on the sea for 10 minutes!! However the admiralty have not discovered my weakness yet in this respect as up to this I have been working on land'. ${ }^{119}$ Townsend undertook wireless research for the Navy at Oxford and Woolwich. In 1916 he developed small and robust wavemeters (measuring wavelengths of $800-3200 \mathrm{~m}$ and $3000-12000 \mathrm{~m}$, the sort of frequencies used by radio transmitters during the war). 18 of them would be supplied to the Admiralty in 1918. ${ }^{120}$ Townsend continued to improve the wavemeter after the war, patenting it several times between 1919 and 1921.121

The break with international physics increased after the war. Townsend first ignored and then rejected the rising new quantum theories. In 1915, Niels Bohr reinterpreted Franck and Hertz's 1914 experiment as an important confirmation of his atomic theory, for which Franck and Hertz were awarded the Nobel Prize in 1925. In 1923-1926, the Oxford group measured new ionization potentials which Townsend published as contradicting Franck and Hertz's results and refuting the quantum theory of electron collisions. ${ }^{122}$ Meanwhile the Ramsauer effect of slow electrons was increasingly viewed as a quantum phenomenon, which led Max Born to apply wave mechanics to collision processes from 1926 onwards. Slow electrons were studied in the 1920 s by Townsend and his collaborators (Bailey, Skinner and White), who constructed a 'Townsend effect' as a nonquantum alternative to the Ramsauer effect. ${ }^{123}$ Between 1924 and 1953, Townsend attended no international scientific gathering. His laboratory has been described as 'an isolated island', whose inhabitants 'were rather impatient in explaining unfamiliar concepts' and only 'occasionally carrying

118 Townsend to Rutherford, 12 Feb 1915, CUL, Add7653, T86.

119 Townsend to Langevin, 11 November 1915, LP, L76/75.

${ }^{120}$ Instrument $n^{\circ} 30, C L A$; Contract with the Admiralty to supply 18 wavemeters, $1918, T P$, IV/11; Diagrams for wavemeter IV (7 sheets, nd), TP, IV/16.

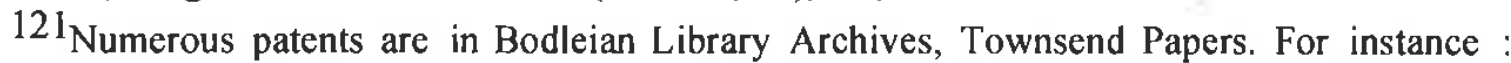
'Improvements in electric wave meters', Patent $\mathrm{N}^{\circ} 129579,4 / 02 / 1919$ (IV, 13); 'Improved method of and means for measuring the length of electric waves', with James Herbert Morrell, Patent $\mathrm{N}^{\circ} 177938,15 / 02 / 1921$ (IV, 18). See also Townsend, 'Oscillations obtained by coupling a secondary circuit with a continuous wave valve oscillator', Radio Rev., $\mathrm{n}^{\circ} 8$ (May 1920). Townsend and J. H. Morrell, 'Electric oscillations in straight wires and solenoids', $P M$, $6,42,(1921), 265$.

122 Hon (1989), 87-88, 98-101.

${ }^{123}$ Im (1995), 280, 282-7. 
the flag into a far land'. ${ }^{124}$ In 1938 , his lectures being increasingly out of touch, the University tried to convert his chair into one for theoretical physics. 125

Townsend withdrew to Oxford in his personal life also. After the war, he apparently stopped visiting and exchanging letters with Rutherford and Langevin. In 1911, he married Mary Georgiana Lambert. She became 'a delightful hostess' and an active worker in municipal affairs, an alderman, twice mayor, and an honorary freeman of the City of Oxford. ${ }^{126}$

By his lifestyle, and though he had neither independent means nor a country-house, Townsend resembled other Oxford physicists, like Dobson, Merton, Jackson, these wealthy 'Clarendonian gentlemen' depicted by Jack Morrell. ${ }^{127}$ His favorite hobbies were tennis, riding, shooting, and fox-hunting. He was often seen riding on his horse to his laboratory, even though his house in Banbury road was less than 10 minutes walk from it, a practice which must have been noticeable in streets gradually invaded by cars from the Morris factories. Townsend's social manners particularly suited the college life of an Oxford character. According to his friend and obituarist von Engel, 'he was a charming conversationalist and his stories about people he had met and other anecdotes of an amusing nature were always well received in common-rooms and at private parties'. ${ }^{128}$ Townsend never socialized with physicists of the Clarendon Laboratory. The only exception was Derek A. Jackson, whom he frequently visited in the laboratory to talk fox-hunting. ${ }^{129}$ Jackson was a very wealthy man; he bought himself expensive spectrographs ${ }^{130}$, moved in artistic and aristocratic circles, had six wives, owned horses which he rode when foxhunting and competing at important race meetings. ${ }^{131}$ His friendship with Townsend was favoured by their common passion for aristocratic hobbies, sarcastic jokes, eccentricity and country life.

After several decades in Oxford, Townsend's scientific and social identity had dramatically changed. I would suggest that this owes much to the cultural idiosyncracies of Oxford science, to its pattern of socialization,

${ }^{124}$ Engel (1957), 269.

125 Morrell (1992), 304.

126 von Engel, 'Townsend, Sir John Sealy Edward (1868-1957)', DNB 1951-1960, 983-5. On p. 985.

127 Morrell (1992), 275-8.

128 von Engel (1957), 268-269.

${ }^{129}$ B. Bleaney, 'The Physical Sciences in Oxford, 1918-1939 and Earlier', Notes and Records of the Royal Society of London, 48 (1994), 247-261, p. 260.

130 Nicholas Kurti, 'Oxford reminiscences', nd, p. 4.

${ }^{131}$ Morrell (1992), 278. 
and to its model of gentlemanly scientist. Analysing William Perkin's later career in Oxford, Morrell recalled that 'Oxford's structures and interests' were 'inimical' to industrial research. Perkin's integration could therefore have been a 'lamentable failure'. But it was a success, an 'Indian summer' due partly to 'his character, which was amiable and endearing', and partly to 'his wide interests in music, horticulture, hospitality and travel'. ${ }^{132}$ By contrast, Frederick Soddy's settlement was a notable social failure, which owed much to the incompatibility of his personality and social manners with Oxonian codes. ${ }^{133}$ Oxford was clearly a place which required adaptation from newcomer scientists. ${ }^{134}$

The contrast between Townsend's evolution and other ion physicists from the Cavendish Laboratory is striking. Between the wars, Langevin became a French 'intellectuel', a communist fighting fascism, a reformer of university education, an ardent proponent of relativity and quantum physics, and a divorced man. ${ }^{135} \mathrm{Mc}$ Lennan was involved in the institutional making of the Canadian physics community and became 'the best known and most influential physicist in Canada'. ${ }^{136}$ Like Townsend in Oxford, each ion physicist met a specific national and cultural context; each one adapted himself to it, and shaped accordingly his scientific and social practices, and his public and private identity.

\section{Conclusion}

Cambridge ion physics may be characterized firstly by its technical practices: it was a group of physical effects to study, and a set of instruments, concepts and methods to produce and investigate those phenomena. But it was also a system of intellectual and professional values: some norms of accuracy; research held as a priority far above teaching; a passion for 'fundamental questions' and a disdain for applications and engineering; a model of a research group being composed of talented investigators working on different but related lines under the direction of a charismatic genius; and a pedagogy based on collaborations between master and apprentice at the bench and at the writing desk. The solidarity and the robustness of those components was particularly visible in the ion diaspora: each physicist trained in Cambridge tried to reproduce in his new laboratory the material, intellectual and social culture of the Cavendish. It

\footnotetext{
132 Morrell (1993), 122-3.

${ }^{133}$ A. D. Cruickshank, 'Soddy at Oxford', BJHS, vol 12, nº 42 (1979), 277-288.

${ }^{134}$ See also Howarth (1987), p 353.

${ }^{135}$ Bernadette Bensaude-Vincent, Langevin. Science et vigilance, Belin, Paris, 1987.

${ }^{136}$ Gingras (1991), p. 122.
} 
was also manifest in the local contrasts, a clear example being the conflict between the two Montréal groups: Barnes' on calorimetry was very different from Rutherford's built on the Cavendish model.

From 1901 to 1914, Townsend built his Electrical Laboratory on the Cavendish model and strengthened its position within Oxford University. He reformed the curriculum to create and expand a student clientele for his laboratory instruction. He accelerated the discredit of Clifton to capture part of his resources. He allied himself to the local proponents of technical education, which resulted in the building of a new laboratory funded by the Drapers' Company. He induced his demonstrators and students to experiment and publish in scientific journals. His department became a research centre on gaseous ions, whose instrumental equipment, precision norms, organisational structure and professional ideals were clearly inherited from the Cavendish Laboratory. In the international context of physics, Townsend built a disciplinary niche in which he secured his leadership.

Each ion physicist locally met a rather contingent set of actors, but also long-term structural constraints and cultural inheritances. Langevin, for instance, experienced the French hostility to atomism. In a similar way, Townsend encountered several peculiarities of the Oxford system, such as the institutional and scientific domination of chemistry to physics, the independence of college fellows in a collegiate university, and the Oxford model of the gentlemanly scientist.

\author{
Benoit LELONG \\ Maison Française d'Oxford
}

\title{
BIBLIOGRAPHY
}

Henri Abraham et Paul Langevin (eds), Les quantités élémentaires d'électricité. Ions, électrons, corpuscules, Gauthier-Villars, Paris, 1905.

Anthony Croft, 'Oxford's Clarendon Laboratory', ms, 1986.

A. von Engel, "John Sealy Edward Townsend, 1868-1957", Biographical Memoirs of Fellows of the Royal Society, 3 (1957)), 257-272.

Isobel Falconer, Theory and experiment in J.J.Thomson's work on gazeous discharge, Thèse de doctorat, University of Bath, 1985.

"Corpuscles, electrons and cathode rays : J. J. Thomson and the 'discovery of electron' ", BJHS, 20, 3 (1987). 241-276. 
"J. J. Thomson and Cavendish physics", in Frank James (ed), The development of the laboratory. Essays on the place of experiment in industrial civilization, Mc Millan Press, London, 1989. 104-117.

J. Fudano, Early X-ray research at physical laboratories in the United States of America, circa 1900: a reappraisal of american physics, thèse de doctorat, University of Oklahoma, 1990.

P. Galison et A. Assmus, "Artificial clouds, real particles", in D. Gooding, T. Pinch, S. Schaffer (eds.), The Uses of Experiment. Studies in the Natural Sciences, Cambridge University Press, Cambridge, 1989, 225-274.

Y. Gingras, "La réception des rayons $\mathrm{X}$ au Québec: radiographie des pratiques scientifiques", in Fournier, Gingras, et Keel (eds), Sciences et médecine au Québec. Perspectives sociohistoriques, IRQC, Montréal, 1987. 69-86

, Physics and the rise of scientific research in Canada, Translated by Peter Kearing, Mc Gill-Queen's University Press, Montréal, 1991.

Tom Girtin, The triple crowns: a narrative history of the Drapers' Company, 1364-1964, Hutchinson, London, 1964.

Graeme Gooday, 'Precision measurement and the genesis of physics teaching laboratories in Victorian Britain', unpublished $\mathrm{Ph}$. D. thesis, University of Kent at Canterbury, 1989.

'Precision measurement and the genesis of physics teaching laboratories in Victorian Britain', BJHS, 23 (1990), 25-51.

Willem Hackmann, 'Sonar, Wireless Telegraphy and the Royal Navy: Scientific Development in a Military Context, 1890-1939' in Nicolaas A. Rupke, Science, Politics and the Public Good, MacMillan Press, 1988, 90118.

J. L. Heilbron, H. G. J. Moseley. The life and letters of an English physicist, 1887-1915 (Berkeley, 1974).

, 'Physics at Mc Gill in Rutherford's time', in Mario Bunge and William R. Shea (eds), Rutherford and Physics at the turn of the century, Dawson and Science History Publications, New York, 1979, 42-73. 
Giora Hon, 'Franck and Hertz versus Townsend : a study of two types of experimental error', HSPS, 20/1 (1989), 79-106.

Janet H. Howarth, "Science Education in late-Victorian Oxford: a Curious Case of Failure?", English Historical Review, 102 (1987), 334-371.

VII (forthcoming).

"Oxford for the Arts ? The Natural Sciences 1880-1914", HUO

H. E. Hurst, "Recollections of the study of physics in Oxford at the beginning of the twentieth century", Oxford magazine, (14 Nov 1969), 5960 .

Gyeong Soon Im, 'The formation and development of the Ramsauer effect', HSPS, 25/2 (1995), 269-300.

Rev. Arthur H. Johnson, The History of the Worshipful Company of the Drapers of London, Clarendon Press, Oxford, 5 vols, 1914-1922.

Dong-Won Kim, "J.-J. Thomson and the emergence of the Cavendish school, 1885-1900", BJHS, 28, 2, 97, 1995, 191-226.

J. Mehra, The Solvay Conferences on Physics. Aspects of the development of physics since 1911, D. Reidel, Dordrecht-Holland/Boston-USA, 1975.

J. B. Morrell, "Research in Physics at the Clarendon Laboratory, Oxford, 1919-1939", HSPS, 22 (1992), 263-307.

"W. H. Perkin, Jr., at Manchester and Oxford: from Irwell to Isis", Osiris, 8 (1993), 104-126.

, "The non-medical sciences, 1919-1939", in Brian Harrison (ed.), The history of the University of Oxford. Volume VIII. The twentieth century (Oxford, Clarendon Press, 1994), pp. 139-163.

Romuald Sviedrys, "The rise of Physics Laboratories in Britain", HSPS, 7 (1976), 405-436.

J.-J. Thomson, Conduction of Electricity through Gases, Cambridge University Press, Cambridge, 1st edition 1903, 2nd edition 1906.

J. S. E. Townsend, Electricity in Gases, Oxford University Press, 1915. 